\title{
PECULIARITIES OF TEACHING THE RUSSIAN LANGUAGE IN U.S. UNIVERSITIES (WITH THE EXAMPLE OF SEWANEE: THE UNIVERSITY OF THE SOUTH)
}

\author{
Kathryn Willgus ${ }^{1}$, Valentina N. Kartashova ${ }^{2}$ \\ ${ }^{1}$ Sewanee: The University of the South \\ 735 University Avenue, Sewanee, Tenn. 37383, USA \\ ${ }^{2}$ Yelets State Ivan Bunin University \\ Kommunarov str., 28, Yelets, Russia, 399770
}

\begin{abstract}
This article presents the peculiarities of teaching Russian as a foreign language of students at Sewanee: The University of the South (USA). The American system of pedagogical education of foreign language, with its high mobilization potential from the position of participant in the educational process, is analyzed. Description of the main trends of the higher education system of the United States, making it highly competitive in the global educational space, is given. It is stated that recently the importance of studying foreign languages in the country has significantly increased; some of the most popular foreign languages are listed. Russian as a foreign language is one of the top seven languages studied in American universities. An attempt to justify the reasons why American students prefer to study Russian language is made. The overview of educational programs in the field of training and possibilities of exchange programs for students in the target language country are presented. The basic methods and techniques of language teaching, as well as additional activities in the framework of a club of Russian language, which increase the motivation and quality of student learning, are described. In the conclusion, the authors highlight that the process of modernization of vocational language education in the U.S. is through their variability and pluralism.
\end{abstract}

Key words: Russian, foreign language, teaching Russian, University of the South, Russian Department, Sewanee, study abroad, organization to the course of study, personal study, Russian club

\section{Introduction}

Scientific-pedagogical and empirical study of the American system of pedagogical foreign language education, which has a high mobilization potential, may be a source of new ideas. American Universities strive to meet the most advanced requirements, both in terms of theoretical developments and practical research. "The most important trends of the higher education system in the United States are: globalization, technologization, computerization, internationalization, striving to strengthen its position in the global education market" (Sabirova, Akmaeva, 2014: 21).

A striking manifestation of these trends in the higher education system of the USA makes it highly competitive in the global educational space. A huge number of universities, colleges and language schools with high ratings attract young people from around the world. To get a higher education in the United States is the dream for many people. 
Learning English is critical for thousands of people. This is understandable because the English language becomes a tool of international communication. But what about the study of foreign languages in America?

\section{Foreign Languages in US Education}

Philosophers of the American system of foreign-language education rely on UNESCO's priorities in promoting the use of bilingual and multilingual education methods, reliance on their native language in order to achieve inclusiveness and improve the overall quality of education in accordance with the principle of the equality of all cultures and languages.

The current US educational system, which has developed under the influence of historical, economic and social factors, is characterized by a number of features that in many respects distinguish it from Western European standards. It should be noted that the United States lacks a unified state education system, and each state has the right to determine its structure independently.

In teaching foreign languages, university professors turn to the writings of prominent US educators F. Lamkin, D.M. Marchi, L. Hinkle, R. Abraham, whose works use models and basic principles developed by L. Bloomfield (1942), H.D. Brown (1987), J. Dunkel (1948), P. Hagboldt (1935), Ch. Handschin (1940), C. Jack (2005), S. Krashen (1983), R. Lado (1964), J.S. Richards, T.S. Rodgers (2001), B. Rifkin (2001) et al.

Professor Hinkle's justification of the importance of foreign languages for the students of North Carolina State College still rings true today: "Nations and people are closer today than ever before in the history of the world. Never before was there a time when there was a greater demand for mutual agreement amongst the peoples of the earth. Through the language of a people we get an insight into their life that can be had in no other way. Their modes of thinking, their aspirations, are revealed to us first hand. We come to know them personally, as it were, and with this knowledge there comes mutual understanding that makes for the solutions of many of our life problems. Hence, for these reasons, we hold that the study of languages is preeminently practical for us."

The Association of the Modern Language publishes the statistics of the popularity of foreign languages in higher educational institutions in the United States every four years (English is not taken into account, but sign language used by the mute is taken into account), where data is summarized for all universities (colleges and universities). The majority of educational institutions have courses or Faculties of foreign languages. The analysis of statistics shows that the significance of foreign languages has recently increased significantly. Today, Spanish language is the most popular among American students, and its popularity is steadily growing (perhaps because of the constant increase in the number of Hispanic Americans). The second most popular language is French, German holds the third place. The top six also include Italian, Japanese, and Chinese, which are becoming more popular every year (http://community.livejournal.com/ omnibusrebus/43550.html).

The Russian language holds the seventh place - it is studied by 24.8 thousand students, about the same as a decade ago. According to the Association of the Modern Language, outbursts of interest in the Russian language in the United States were recorded twice in 2000 (following Perestroika - 44.6 thousand students studied Russian then) and in 
1968 (following the Cold War, 40.7 thousand students). Nowadays, the Russian language bypasses other languages by only one important indicator: the number of students who study it at an advanced level.

"In the USA, Russian is considered belonging to the less-commonly taught languages group (rarely taught languages) and now has the status of a Critical Language - a language which only a small number of people speak and which demands bigger studying therefore the government (which requires additional government resources to be taught in schools" (Prokhorov, 2016: 65). The basic principles in a learning of foreign language have been formulated in Standards for Foreign Language Learning in the 21st Century (1999), known as "The Five C's." These standards describe the "what" (content) of world languages learning and form the core of standards-based instruction in the world languages classroom. They include Communication, Culture, Connections, Comparisons, and Communities.

The communication standard stresses the use of language for communication in "real life" situations. It emphasizes "what students can do with language" rather than "what they know about language." Students are asked to communicate in oral and written form, interpret oral and written messages, show cultural understanding when they communicate, and present oral and written information to various audiences for a variety of purposes.

Cultural understanding is an important part of world languages education. Experiencing other cultures develops a better understanding and appreciation of the relationship between languages and other cultures, as well as the student's native culture. Students become able to better understand other people's points of view, ways of life, and contributions to the world.

World languages instruction must be connected with other subject areas. Content from other subject areas is integrated with world language instruction through lessons that are developed around common themes.

Students are encouraged to compare and contrast languages and cultures. They discover patterns, make predictions, and analyze similarities and differences across languages and cultures. Students often come to understand their native language and culture better through such comparisons.

Extending learning experiences from the world language classroom to the home and multilingual and multicultural community emphasizes living in a global society. Activities may include: field trips, use of e-mail and the World Wide Web, clubs, exchange programs and cultural activities, school-to-work opportunities, and opportunities to hear speakers of other languages in the school and classroom.

\section{Experience of Teaching Russian as a Foreign Language}

Let's turn to the experience of teaching Russian as a foreign language at the University of the South (U.S.).

The Russian Department at Sewanee: The University of the South offers a wide variety of knowledge on Russian linguistic and cultural topics in a tightly-knit, supportive environment that rivals programs offered by larger, more fully endowed Russian departments across the States. Difficulties do exist in teaching foreign language in the US, mainly the issue of time constraints. A typical university student takes three to four courses during each academic term, and these courses are usually each fifty minutes long. Each class will meet up to three times a week, bringing a total of two and a half to three 
hours of classroom study each week. Due to the small size of both the faculty and students, Russian majors at Sewanee frequently only take one or two Russian language courses each semester. Despite the comparatively short hours the professors in the Russian department can spend with their students, the Russian department at Sewanee has proudly held a record of seven consecutive years of Fulbright Grants, the prestigious research and teaching award granted by the United States Department of State, being granted to its students.

Students at Sewanee who would like to major or specialize in Russian have to follow a loose set of requirements that ensures that the students receive a well-rounded education in Russian language and culture, but still allows for the students to personalize their education. Students pursuing a Russian major must first do foundation courses in Russian language for three semesters. Then, they must take two courses of Russian language at the advanced level. In addition to language, students must take five courses from a variety of cultural and literary topics. In total, a student must complete a minimum of eight full credit courses in the Russian department to receive a degree in Russian. Studying abroad in Russia or another Russian speaking country during a semester or a summer of the student's study is strongly encouraged. Students may study abroad, often at fixed and affordable rates, with programs like American Councils, Bard-Smolny, the Institute of International Education, and the Council on International Education Exchange.

Students in the Russian department at Sewanee have varied interests and are given the opportunity to pursue them through a variety of courses. Students interested in literature and language can take courses like Dostoevsky (in English), Nabokov (in English), Composition and Conversation (in Russian), Russian Language through Film (in Russian), Gender in 20th and 21st Century Literature and Culture (in English), Putin's Russia and Protest Culture (in English), and the 20th Century (in Russian). The department also offers courses on Environmentalism and Ecocide in Russia, the 19th Century, Representation of the Caucasus in Russian Film, Soviet Film, Russian Civilization, Tolstoy and many more (Sewanee Russian).

In Dostoevsky, students begin by reading short stories, like White Nights, working their way up to Notes from Underground, then Crime and Punishment and The Brothers Karamazov. In Nabokov, students read many of his short stories and novels, notably, Spring in Fialta, The Return of Chorb, The Vane Sisters, Signs and Symbols, Lolita, The Real Life of Sebastian Knight, Invitation to a Beheading, Pnin, and Pale Fire. "In training a teacher of Russian the emphasis is placed on wide humanitarian education" (Volovikova, 2008: 121). In Composition and Conversation, students spend much of their time talking about different subjects in order to learn new vocabulary and common constructions, as well as partaking in cultural activities like listening to music or watching cartoons in order to grasp new conversational styles. In Russian Language through Film, students watch many classic Soviet films, such as Zolushka, Moscow Doesn't Believe in Tears, The Irony of Fate, Circus, The Cranes are Flying and Shurik's adventures. In Gender in 20th and 21st Century Literature and Culture, students watch films and read literature through the lens of gender representation. Some of the most notable pieces we worked with were Chekhov's Agafya and Lady with the Little Dog, Cement by Gladkov, Olesha's Envy, and more contemporary works from authors such as Tolstaya and Vasilenko. In Putin's Russia and Protest Culture, students learn about contemporary Russia, from the fall of the Soviet Union; the Chechen 
Wars; Putin's presidency and his style of leadership; protests and protest groups like Voina, Femen, and Pussy Riot. In 20th Century, students read short stories from authors Babel, Zamyatin, Solzhenitsyn and others in the original Russian. All of these courses offer both analysis of classic Russian art and culture side-by-side with historical context and information.

In terms of language instruction, the professors at Sewanee are not always methodical. There is a clear organization to the course of study, but it is often difficult to teach linguistic topics in a straight, sequential order. In the lowest level, students begin with the alphabet and phonemes - practicing how to write and say each letter is, of course, fundamental to speaking. Students begin speaking almost immediately after mastering the alphabet; even if students do not always understand what they are saying, it is important to the professors that they begin making these sounds and formulating sentences. Students learn basic vocabulary: personal pronouns and possessive pronouns, animals, household items, adjectives, important verbs and other everyday words. Grammar is unavoidable at all levels of instruction, but students generally do not begin the in-depth exploration of the Russian case system until the third term. The order in which students learn the cases is different from the order in which Russian school children learn them, which can likely be attributed to an inherent linguistic and intellectual difference in native speakers and second language learners. Whereas in school, small Russian children learn nominative, genitive, dative, accusative, instrumental, and prepositional cases; students as Sewanee learn nominative, prepositional, genitive, accusative, dative, and instrumental. Students spend most of the third term mastering each case on its own, then constructing full thoughts and sentences with multiple cases. During this grammatical instruction, students are slowly introduced to more difficult topics, such as possession, in-depth description, and verbs of motion. In the fourth term, students spend much of their time practicing grammar, mastering verbs of motion, and being introduced to difficult Russian concepts like the reflexive personal pronoun sebya. It is only after these four semesters of foundational language study that students are able to closely study more nuanced topics like conversation, types of mood, verbs of motion with prefixes, and interpretive language.

Instruction in the classroom generally comprised a number of tactics, including but not limited to study with textbooks, audio-visual listening activities, lectures, and in-class discussion. Professors at Sewanee use the following textbooks in teaching the Russian language:

В пути, Грамматика в контексте, (2006),

Animation for Russian Conversation, and Russian Stories: a Dual Language Book (2013),

Russian Language and People (2006),

Russian 2: A Communicative Russian Course (2009),

Troika: A Communicative Approach to Russian Language, Life, and Culture (Russian (2012),

Russian Stories: A Dual-Language Book (Dover Dual Language Russian)(1961),

Grammatika v kontekste: Russian Grammar in Literary Contexts (1996).

These texts enhance instruction by introducing and explaining conversation topics like family and food, showing literary grammatical and syntactical constructions in context, and putting forth new vocabulary and grammar topics through authentic and culturally relevant Russian programs (see Table 1). While these methods help introduce 
new ideas, often the most helpful way to learn was through in-class activities and discussions. Many of the Russian courses at Sewanee have a "Russian only" policy, which encourages and even requires students to only speak Russian in the classroom. Many classroom and homework activities revolve around language training and practice of newly introduced topics, like creating compositions, writing dialogues and playing games using new words and constructions.

Table 1

В пути (Table of Contents)

\begin{tabular}{|c|l|}
\hline Chapter Number & \\
\hline 1 & You, your family, university life \\
\hline 2 & Class schedules, daily routines, and extra-curricular activities \\
\hline 3 & Extended family, family history, marriage and divorce \\
\hline 4 & Computers, the internet, and scientific discoveries \\
\hline 5 & Where you live \\
\hline 6 & People's appearance, personality traits, and personal relationships \\
\hline 7 & Theatre, music, ballet \\
\hline 8 & Travel and tourism \\
\hline 9 & Life in a city, driving, directions \\
\hline 10 & Clothing, weather, illnesses, natural disasters \\
\hline 11 & Food and cooking \\
\hline 12 & Sports, literature, movies \\
\hline
\end{tabular}

L. Bloomfield indicated the need of the creation of the system of oral training exercises therefore the American methodologists in line with the structural linguistics "attach great significance to the intensive oral training exercises (drills) with such a number of repetitions which provide learning material by heart" (Benson, 2011: 49). Personal study is a difficult topic to gauge because it varies by individual. Some students are visual learners and like to see things explained in writing or with images. Others are auditory learners, who learn best by speaking and listening to others. For some, foreign language instruction comes easily, while others may have biological differences such as "verbal intelligence, phonological processing ability, and long-term memory capacity" that prevent them from quickly and efficiently acquiring second language skills (Clyne, 2001:98). Aside from biological factors, students often struggle with psychological difficulties as well. Variables like anxiety, motivation, and confidence "may strongly enhance or inhibit second language acquisition by playing a critical mediating role between the linguistic input available in the educational setting and the student's ability to learn" (Clyne, 2001). In learning a foreign language a student's age plays a significant role, as children can learn these verbal skills more easily, due to the plasticity of their brains (Clyne, 2001). Unlike in Russia, where foreign languages study begins as early as the first grade, language study in the U.S. usually begins around grade 8 , or at age 14 , which usually makes mastery more difficult. Aside from completing homework assigned for courses and speaking with their colleagues and the Russian House Director, some students find it helpful to write sentences, create lists, and make tables for information in order to develop their language skills. While study tactics and study time vary from student to student, it is almost certain that most students will spend time outside of class doing homework, writing papers, and preparing for tests and examinations. 
The Russian Department at Sewanee offers many supplemental activities that enhance the students' language learning. The Russian Club at Sewanee meets to celebrate Russian holidays like Maslenitsa, watch contemporary Russian films like Stilyagi and Leviathan, and learn about other aspects of culture. Every year, the Russian Department chooses a graduate student from the Liberals Arts Department at St. Petersburg University to move to Sewanee for a year to assist the professors in Russian language teaching. This Russian graduate works closely with students majoring in Russian - living among them, planning and hosting events for the Russian Club, and engaging in weekly Russian conversations required by the professors. Despite some systematic barriers faced by both students and professors, Sewanee and its Russian Department strive to provide a rich and well-rounded education to students majoring in Russian.

It is difficult to gauge why American students choose to learn Russian, but it is likely due to its global importance as the fifth most commonly spoken language in the world (Sewanee Russian). Whether a student is interested in politics, history, or literature, Russia remains a leading influence on both the global economy and modern culture. Of 30,000 American students that study Russian, about 9,000 will continue their study past the elementary level, and only about 900 of those will choose to study abroad in Russia (Koshkin, 2013). At Sewanee, the class of 2016 had seven Russian majors out of 340 graduating seniors (Sewanee Registrar). These graduating members have received jobs such as the Fulbright Grant, teaching at English First in Moscow, translating at the St. Petersburg Music Hall, assisting the Europe/Eurasia Area Studies Program at the Foreign Service Institute in Arlington, Virginia, private banking in Boston, Massachusetts, and assisting at the Institute for International Education in New York City. Students who study Russian in America have many possibilities for the future, including careers in translation and interpretation, teaching, diplomacy, and national security (University of Melbourne). Whether an American student discovers their passion for Russian through popular children's films, Soviet propaganda, or classic literature, a degree in Russian language opens doors to a vast number of opportunities all over the world.

\section{Conclusion}

Curricula, programs, and quality assurance technologies for the training of foreign language teachers in American universities show that the process of modernization of professional language education occurs in the context of their variability and pluralism. In this regard, at present, mixed methods of foreign language teaching, where traditional and innovative methods are combined, are becoming increasingly popular in the United States. Language teaching is focused on the fastest achievement of communicative goals, on the formation of communicative competence, and not on the study of grammatical forms and the consistent introduction of one rule after another. Most of the time is assigned to the implementation of communicative tasks, and the study and training of language forms are carried out by students at home with the help of specially developed exercises and explanations.

In our opinion, the described technique of teaching the Russian language in comparison with the approaches existing in the Russian methodology nowadays besides its advantages has a number of disadvantages: 
- it is believed that the mastery of a foreign language should be based on the same principles as the mastery of the mother tongue;

- excludes the role of cognitive processes, which affects the assimilation of the material;

- denied the need to work on language form language; making as the primary goal of teaching communicative competence, the authors do not consider that linguistic competence is part of it;

- training on the basis of oral lead and a long oral period does not contribute to the development of all types of speech activity, inhibit the establishment of sustainable linkages between sound and graphic images of the phenomena. The existing training materials and grants on training in Russian aren't ideal. Many of them sin with excessive academism which frightens off students, or offer not the absolutely correct linguoculturological information distorting reality. It is caused in many respects by the fact that some textbooks are written not with native speakers, and English-speaking authors who have the image of Russian and culture.

Despite another decline in U.S.-Russia relations, interest in Russia among American students is steadily growing. This indicates that exchange programs remain a powerful tool for rooting out the Cold War mentality.

\section{REFERENCES}

About Sewanee. The University of the South Site. Available at: www.sewanee.edu/academics/russian/ about/. Accessed 29 April 2017.

Asher, J. (1984). Language by command. The Total Physical Response approach to learning language. The way of learning, (6), 35 .

Benson M. (2011). The main problems of a technique of teaching foreign languages in the USA. Foreign Languages at School, (8), 48-55. (In Russ.).

Bloomfield L. (1942). Outline guide for the practical study of foreign languages. Baltimore.

Careers for Russian Majors/ Diploma of Languages in Russian. University of Melbourne Site. Available at: www.students.unimelb.edu.au/?a=1268189. Accessed 29 April 2017.

Clyne, S. (2001). Psychological factors in second language acquisition: Why Your international students are sudando la gota gorda (Sweating Buckets). Teaching for Our Times, 3, 96-101.

Sewanee: the University of the South Site. Available at: www.registrar.sewanee.edu/downloads/enrollmentreports/U_of_South_Enrollment_Report,_Advent_2016.pdf. Accessed 29 April 2017.

Dunkel, H.B. (1948). Second-Language Learning. Boston.

Hagboldt, P. (1935). Language Learning. Some Reflections from Teaching Experience. Chicago: University of Chicago Press.

Handschin, C.H. (1940). Modern-language teaching. World Book Company.

Kagan, O., Miller, F.J., \& Kudyma, G. (2005). Vputi: Russian Grammar in Context. Upper Saddle River, NJ: Pearson Prentice Hall.

Koshkin, P. (2013). Why American students will go to Russia. Russia Beyond the Headlines. Available at:www.rbth.com/international/2013/09/05/why_american_students_still_go_to_russia_29551. html. Accessed 29 April 2017.

Krashen, S.D., \& Terrell, T.D. (1983). The natural approach: Language acquisition in the classroom. Hayward, CA: Alemani Press. 
Lado, R. (1964). Language Teaching: A Scientific Approach. New York.

Langran, J., Veshnyeva, N. (2013). Russian 2: a communicative Russian course. Student Workbook with free audio CD (Russian). Ruslan Ltd.

Merrill, J., Mikhailova, J., Alley, M. (2009). Animation for Russian Conversation. Focus Publishing/R Pullins \& Co.

Nummikoski, M. (2012). Troika: A Communicative Approach to Russian Language, Life, and Culture (Russian). John Wiley \& Sons.

Prokhorov, N.N. (2016). Features of Teaching Russian Language as Foreign in the American Higher Education Institution. Scientific Search. 1 (1), 65-68. (In Russ.).

Richards, J.C., \& Rodgers, T. (1987). Method: Approach, Design and Procedure. In: M.H. Long and J.C. Richards (eds.). Methodology in TESOL. A Book of Readings. Boston. doi: 10.2307/3586789

Richards, J.S., Rodgers, T.S. (2001) Approaches and Methods in Language Teaching (2nd edition). Cambridge University Press.

Richards, J.S., Jack C. (2005). Communicative language teaching today. SEAMEO Regional Language Centre.

Rifkin, B. (1996). Grammatika v Kontekste: Russian Grammar in Literary Contexts. McGraw-Hill.

Rifkin, B. (2001). Training in Russian in the USA (Testing Technique). Higher Education abroad, (5), $139-146$.

Rubin, J., Thompson, E. (1993). How to be a more successive in Language Learner. Heinle and Heinke.

Sabirova, D.R., Akmaeva, A.S. (2014). Podgotovka uchitelya inostrannogo yazyika v usloviyah funktsionirovaniya standartov vyisshego yazyikovogo obrazovaniya v SSHA. Fundamentalnyie issledovaniya, 6 (6). 1282-1285. (In Russ.).

Shardakova, M. (2016). American Learners' Comprehension of Russian Textual Humor. The Modern Language Journal, 100 (2), 466-483.

Standards for Foreign Language Learning in the 21st Century (1999). Available at: http://www.actfl. org/sites/default/files/pdfs/public/StandardsforFLLexecsumm_rev.pdf. Accessed 20 April 2017.

Struve, G. (1961). Russian Stories: A Dual-Language Book (Dover Dual Language Russian). Kindle Edition. New York.

Volovikova, M.L. (2008). Historical and pedagogical aspects of development of the theory and practice of multicultural education in the USA. Rostov-on-Don: Rostov University Publ. (In Russ.).

\section{Article history:}

(C) Willgus, K., Kartashova, V.N., 2017

Received 4 April2017

Revised 1 June 2017

Accepted 14 June 2017

\section{For citation:}

Willgus, K., Kartashova, V.N. (2017). Peculiarities of Teaching the Russian Language in U.S. Universities (with the Example of Sewanee: the University of the South). RUDN Journal of Psychology and Pedagogics, 14 (3), 301-310. DOI 10.22363/2313-1683-2017-14-3-301-310

\section{Bio Note:}

Kathryn Willgus - Assistant teacher of English, Sewanee: The University of the South, C'16. Fulbright U.S. Student Award, 2016-2017 (Sewanee, USA). E-mail: willgk10@sewanee.edu

Valentina N. Kartashova - Doctor of Pedagogical Sciences, Full Professor, Head of Institute of Philology Yelets State Ivan Bunin University (Yelets, Russia). E-mail: kartashova_vn@mail.ru 


\title{
ОСОБЕННОСТИ ПРЕПОДАВАНИЯ РУССКОГО ЯЗЫКА В ВУЗАХ США (НА ПРИМЕРЕ УНИВЕРСИТЕТА СЕВАНИ)
}

\author{
К. Вилгус ${ }^{1}$, В.Н. Карташова ${ }^{2}$ \\ ${ }^{1}$ Севани: университет Юга \\ Юниверсити Авеню, 735, Севани, Тененси, США, 37383 \\ ${ }^{2}$ Елецкий Государственный Университет И.А. Бунина \\ ул. Коммунаров, 28, Елец, Липецкая обл., Россия, 399770
}

\begin{abstract}
В данной статье представлено описание особенностей обучения русскому языку как иностранному студентов педагогического образования в университете Севани (США). Анализируется с позиции участника образовательного процесса опыт американской системы педагогического иноязычного образования, обладающей высоким мобилизационным потенциалом. Дается описание основных тенденций, характерных для системы высшего образования США, делающих ее высоко конкурентной во всем мировом образовательном пространстве. Констатируется, что за последнее время значимость изучения иностранных языков в стране заметно возросла, перечисляются наиболее востребованные для изучения иностранные языки. Русский язык как иностранный входит в первую семерку изучаемых языков. Делается попытка обоснования причин, почему американские студенты предпочитают изучать русский язык. Представлен обзор образовательной программы по направлению подготовки, возможности дальнейшей стажировки обучающихся в стране изучаемого языка. Описаны основные методы и приемы обучения языку, а также дополнительные мероприятия в рамках клуба русского языка, повышающие мотивацию и качество обучения студентов. В заключении делаются выводы, что процесс модернизации профессионального языкового образования в США происходит по линии их вариативности и плюрализма.
\end{abstract}

Ключевые слова: русский язык как иностранный, изучение русского языка, университет Юга, факультет русского языка в Севани, стажировка за рубежом, учебный план, индивидуальное обучение, русский клуб

\section{История статьи:}

(c) Вилгус К., Карташова В.Н., 2017

Поступила в редакцию: 4 апреля 2017

Принята к печати: 14 июня 2017

\section{Для цитирования:}

Вилгус К., Карташова В.Н. Особенности преподавания русского языка в вузах США (на примере университета Севани) // Вестник Российского университета дружбы народов. Серия: Психология и педагогика. 2017. T. 14. № 3. С. 301-310. DOI 10.22363/2313-1683-2017-143-301-310

\section{Сведения об авторах:}

Вилгус Катрин - ассистент преподавателя английского языка университета Севани: университет Юга, студенческая премия Фулбрайт США, 2016-2017 (Севани, США). E-mail: willgk10@sewanee.edu

Карташова Валентина Николаевна - доктор педагогических наук, профессор, директор института филологии Елецкого государственного университета им. И.А. Бунина (Елец, Россия). E-mail: kartashova_vn@mail.ru 